Most wanted
Computer modellers
draw up hit list for
protein structures
$p 4$

\title{
Ruling on cleaner diesel leaves Republicans facing a dilemma
}

Tony Reichhardt, Washington

The US Environmental Protection Agency (EPA) has issued strict new regulations governing diesel exhaust from vehicles. The move has been hailed as the most significant single action to improve US air quality since lead in gasoline was banned in 1986.

The regulations - issued late last month by the outgoing administration of President Bill Clinton - follow years of feuding between academic and industrial scientists over whether small particles in diesel exhaust are hazardous to human health.

And, observers say, they throw down a gauntlet for Christine Todd Whitman, the governor of New Jersey, who will head the EPA under George W. Bush's Republican administration. Whitman will have to decide whether to keep the rules, and anger some of Bush's industrial supporters, or to resume the arduous scientific advisory process needed to draw up an alternative plan.

The new regulation requires diesel trucks and buses to be fitted with pollution control devices similar to catalytic converters. Because high-sulphur fuels choke the devices, the EPA also ordered a $97 \%$ reduction in the sulphur content of diesel fuel, to 15 parts per million. Vehicle manufacturers must meet the limits beginning with their 2007 models, and diesel refiners must start selling cleaner fuel by June 2006 .

The EPA aims to cut emissions of smogcausing nitrogen oxides and airborne particulate matter. The latter has been tied inconclusively, say the agency's critics - to health effects ranging from asthma to premature death (see Nature 392, 642; 1998). The EPA says that trucks and buses account for about one-third of nitrogen oxides emissions and one-quarter of airborne particulates, or soot.

The American Lung Association welcomed the decision and released poll results suggesting that Americans strongly favour cleaning up diesel exhaust, even if it costs consumers more. The American Petroleum Institute, the US Chamber of Commerce, and several organizations representing farming, oil production, trucking and vehicle manufacturing condemned the new rule,

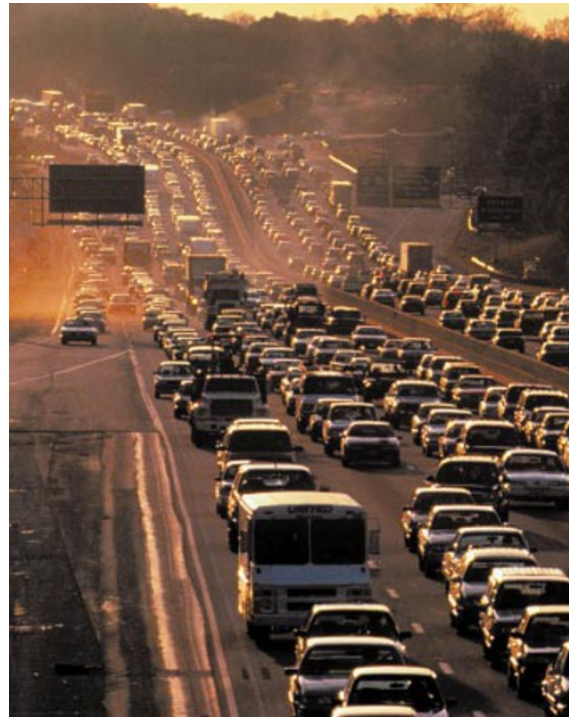

Diesel vehicles face strict new rules on emissions.

citing the costs of compliance and what they call dubious benefits to public health.

But Richard Kassel, a senior attorney with the Natural Resources Defense Council, an environmental lobby group, says that "the oil industry is not speaking with a unified voice" on the issue. Indeed, BP and Tosco, two of the nation's biggest diesel fuel producers, support the rule.

During hearings on diesel regulation in September, Senator James Inhofe, a Republican from the oil-producing state of Oklahoma and outgoing chairman of the Senate subcommittee that oversees clean air legislation, threatened to use Congress's powers to veto any regulation he saw as too stringent.

But, says Kassel, the 1996 Congressional Review Act has never been used successfully to overturn a regulation. Inhofe will not head the clean air subcommittee when Congress reconvenes this month. And Republicans may not want to risk reversing the rule.

Environmentalists may also find an ally in Whitman, whose environmental commissioner from New Jersey testified in favour of the rule during hearings.

A group led by the American Trucking Associations has challenged the EPA's 1999 standards on ozone and particulates. So far the courts have ruled against the EPA, and the matter is now being considered by the Supreme Court.

\section{Human Proteome Index launched}

\section{Alison Abbott}

Large Scale Proteomics, based in Rockville, Maryland, this week launched the Human Proteome Index, a database which subscribers can use to help identify proteins involved in diseases.

The index — the first of its kind — lists and quantifies the complement of proteins expressed in 157 different tissues from a single female donor who died of cardiac arrest. The proteins were identified 'factorystyle' by mass spectrometry after being separated in the different tissues by twodimensional gel electrophoresis.

The index includes over 115,000 different proteins, encoded by an estimated 18,000 different genes. Humans are generally thought to have between 30,000 and 70,000 genes. Large Scale Proteomics - part of the Large Scale Biology Corporation - is expanding the database, using tissues from additional donors, to detect proteins expressed at low levels and to map the cellular and subcellular distribution of proteins.

A Human Proteome Index was conceived in 1980 by Norman Anderson, then at the Oak Ridge National Laboratory in Tennessee, as a large-scale federally funded project, but the idea lost political support. His son, Leigh Anderson, has been the driving force behind the latest effort.

The Human Proteome Index will only be available commercially, says Leigh Anderson, mainly to companies interested in finding markers of tissue damage or disease. 